\title{
EFFECT OF DISTURBANCE ON THE ANT COMMUNITY IN A SEMIARID REGION OF CENTRAL MEXICO
}

\author{
SOMBRA PATRICIA RIVAS-ARANCIBIA* - HORTENSIA CARRILLO-RUIZ - ALICIA \\ BONILLA ARCE - DULCE MARÍA FIGUEROA-CASTRO AND AGUSTINA ROSA \\ ANDRÉS-HERNÁNDEZ
}

\author{
Universidad Autónoma de Puebla \\ Blvd. Valsequillo y Av. San Claudio, Edificio 112 A, Ciudad Universitaria. Col. Jardines de San \\ Manuel, C.P. 72570. Puebla, México. \\ (phone: +22-2-295-500, ext. 2756) \\ *Corresponding author \\ e-mail:sombrar@gmail.com \\ (Received $16^{\text {th }}$ May 2012 ; accepted $22^{\text {nd }}$ July 2014)
}

\begin{abstract}
Ants have been used as indicators of disturbííííance, because of their fast response to environmental changes. However, it is not well defined which disturbance factors are associated with specific changes on the ant community. We evaluated the effect of disturbance on the ant community in a xeric community from central Mexico. Two sites with contrasting levels of disturbance were chosen based on a quantitative index. We compared ant abundance, ant diversity and the main disturbance factors affecting the ant community. Also, we identified the bioindicator species of ants and the feeding guilds. Soil compaction and cattle paths were the most important factors of disturbance within the study sites. These factors probably affect the community of ants by preventing them from colonizing the surrounding vegetation as well as from nesting in the soil. Ant diversity was lower in the disturbed site than in the conserved one. Four ant species were identified as bioindicators of disturbance. Although functional diversity did not differ between sites, the guild of granivore ants was the most affected by soil compaction. This is of great importance because the foraging patterns of granivore ants determining the structure and other aspects of the plant community.
\end{abstract}

Keywords: antropogenic change; bioindicator species; feeding guilds; quantitative disturbance index; soil compaction.

\section{Introduction}

Ants have an important role within the ecosystems because they occupy many different ecological niches. For instance, ants have numerous interactions with different plant species, including seed dispersers, leaf- and seed- predators, and in a few cases, pollinators (Vázquez 1998; Hernández 2005). Some ant species establish mutualistic relationships with a diversity of organisms. For example ants protect aphids and other homopterans from their predators, obtaining sugar-rich solutions produced by the homopterans (Delfino and Buffa 2000). Moreover, several ant species build their nests in the leaf litter, underneath the soil, within woody stems or under the rocks. In all of these cases, activities associated with gallery building by ants favor the mixing of organic matter in soil, as well as enrich and oxygenate the soils (Luque et al. 2002).

Among social insects, ants have the widest geographical distribution (Bolton et al. 2006; Fisher and Cover 2007; Vásquez-Bolaños and Mackay 2004; Vásquez-Bolaños 2007). However, ant diversity and population size are strongly affected by changes in environmental factors such as temperature, humidity, solar radiation and vegetation coverage (Rojas 2001; Grytnes and McCain 2007; Castro et al. 2008). In addition, anthropogenic disturbance may cause changes in the structure and diversity of the ant

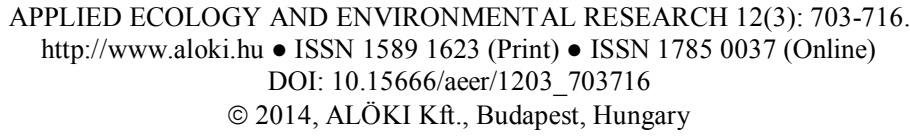


community (Davidson et al. 2003; Del Toro 2009; Brito et al. 2010). Anthropogenic disturbance may cause an increase in soil temperature, and a decrease in humidity and in the abundance of plants and leaf litter. Consequently, these changes may have a negative effect on ant-ant communication since the chemical signals left by worker ants may be washed out by the rain (Carroll and Rich 1983).

Because ants have a fast response to changes in environmental factors and occupy a great variety of ecological niches, they can be good bioindicators of disturbance (Rojas 2001). Several studies have evaluated the effect of disturbance on the abundance, diversity and composition of functional groups of ants within specific ecosystems (Majer 1983; Andersen 1995; Andersen 1997; Bustos et al. 1997; Lobry 1999; Kaspary and Majer 2000; Hoffmann and Andersen 2003; Redolfi et al. 2003; Vittar 2008).

However, those studies have classified the level of disturbance qualitatively. Therefore, it is hard to identify the factors of disturbance that are associated with changes in the ant community. More recently, Martorell and Peters (2005) have proposed a quantitative method to determine the level of disturbance of a particular community. Their method considers 15 variables, including human and cattle activities, and soil degradation. By using Martorell and Peters (2005) method, one can estimate a quantitative index of disturbance and analyze the effect of each disturbance factor on the community of study. Thus, it is possible to establish the relationship between the most important disturbance factors and changes in the community of study. This information, together with the identification of bioindicator species and feeding guilds may provide useful information on the processes and consequences of the disturbance in a particular habitat.

Therefore, through the quantitative estimation of the level of disturbance on a diverse semiarid region from Central Mexico, we selected two sites with contrasting disturbance indexes and identified the species of ants within each community. Particularly, we were interested in determining the effect of disturbance on the relative abundance and diversity of ants, identifying the species of ant that can be used as bioindicators of disturbance. We also, classified the ant community in feeding guilds, establishing the effects of disturbance factors on changes in the functional diversity of the ant community.

\section{Material and Methods}

\section{Study site}

The study was conducted in the Zapotitlan Valley, located within the TehuacanCuicatlan Reserve in the Puebla state, Mexico. The valley is representative of an arid ecosystem and is located at 1400 masl. Climate is semiarid with a mean annual precipitation of $380 \mathrm{~mm}$, recorded mainly during the summer. The mean annual temperature is $21{ }^{\circ} \mathrm{C}$ (Montaña and Valiente-Banuet, 1998). Soils are shallow and rocky, calcic cambiosols and xerosols or litosols (Zavala-Hurtado, 1982). The vegetation in the locality is a xeric shrubland (Rzedowski, 1978), in which columnar cacti dominate the landscape (Valiente-Banuet et al., 1997).

\section{Disturbance index and site selection}

We used the methods proposed by Martorell and Peters (2005) to estimate the disturbance index on 26 different sites within the locality and thus choose two sites with 
contrasting level of disturbance to conduct the study. To estimate the disturbance index, within each site we marked two $50 \mathrm{~m}$ transects separated by $10 \mathrm{~m}$ from each other. On each transect we recorded 15 factors of disturbance from three categories: i) Livestock raising (goat droppings frequency, cattle droppings frequency, browsing, livestock trail density and soil compaction); ii) human activities (fuelwood extraction, human trails density, human trails surface, settlement proximity, contiguity to activity cores, land use and evidence of wildfires) and iii) land degradation (erosion, presence of soil islands and totally modified surfaces). Then, we constructed a data set with the 15 disturbance factors obtained for each site, such as Martorell and Peters (2005) have suggested. A principal components analyses (PCA) was applied to this data set. Data were standardized and combined into a single index. The PCA score of a site is a linear combination of the values recorded for each factor. This allowed us to calculate an index for each disturbance factor by adding only the respective linear terms. The sum of these indices equals the PCA score, so they reflect the contribution of different forms of disturbance in a location. The analysis was conducted in MVSP v. 3.12g (Kovach, 2004).

According to the disturbance index obtained for each site, we choose two sites with contrasting indexes to conduct the present study. The sites with the lowest and highest disturbance indexes were then denominated conserved and disturbed site, respectively.

\section{Ant sampling}

Ant collection was conducted using pitfall traps. Pitfall traps are widely used for collecting terrestrial invertebrates, having the advantage of being inexpensive and facilitating the collection of a great amount of organisms (Andersen, 1991).

In each site, we established two parallel $100 \mathrm{~m}$ transects, separated by $10 \mathrm{~m}$ from each other. On each transect, we placed 10 pitfall traps every $10 \mathrm{~m}$. Five traps were placed on the soil surface, whereas the other half were placed on the surrounding vegetation at $1 \mathrm{~m}$ in height. Tuna was used as bait in each trap (Bestelmeyer and RiosCasanova, 2010). Trapped organisms were collected from the traps every day at 7 and 19 hrs during a 10 days period. As we collected the organisms, the bait on each trap was replaced. All collected ants were preserved in $70 \%$ ethanol. Afterwards, we determined the number of ants collected per species. Ant species were determined by using the identification keys by Mackay and Mackay (1989).

\section{Disturbance effect on the ant community}

Ant abundance was compared between sites and between sampling time within each site by applying a repeated measures ANOVA (Gurevitch and Chester, 1986). A posthoc Bonferroni test (Rice, 1989) was applied in order to determine which species showed significant differences. Data of ant abundance were transformed as $\log _{\mathrm{e}}$ to fit normality. Statistic analysis was conducted on NCSS 2001 (Hintze, 2006).

A Simpson index (Magurran, 1988) of ant diversity was estimated for each site. Diversity indexes were estimated using the software MVSP v. 3.12c (Kovach, 2004).

A canonical correspondence analysis (CCA; Johnson, 1998) was applied to determine the effect of the 15 disturbance factors estimated in each site on the ant community. Then, we constructed a biplot showing the position of each ant species (from both sites) respect to each one of the 15 disturbance factors. In the biplot, disturbance factors are shown as vectors, indicating the direction in which the variable 
increases. The importance of disturbance factors on the distribution of each ant species is indicated by the length and the angle between each vector and the horizontal axis (Ter Braak, 1987). The analysis was conducted in MVSP v. 3.12c (Kovach, 2004).

\section{Feeding guilds}

In order to determine the effect of disturbance on the functional communities of ants in the two sampled sites, we estimated the similarity index of Sörensen modified by Silvestre (2000). The modified index includes the number of functional guilds sampled within each locality and the number of species within each guild. Functional similarity (fs) is very useful when comparing community structure from different sites, assuming that species within each functional guild are ecologically equivalent (Martínez, 1996, Silvestre et al., 2003).

\section{Results}

\section{Disturbance index}

The disturbance indexes for the two sites chosen were 8.93 (disturbed site, D) and 0.27 (conserved site, C). Among the 15 disturbance factors considered for the estimation of the index, cattle paths $(0.963)$ and soil compaction $(0.266)$ had the greatest values for the first component. Disturbance factors associated with human activities had low values. Among these, closeness to sites with human activity $(0.001)$, plant coverage on paths (0.022) and path surface (0.024) were the less important.

\section{Abundance, species richness and diversity of ants}

A total of 5254 ant individuals were collected. The ants collected belong to four subfamilies (Myrmicinae, Pseudomyrmecinae Formicinae Dolichorerinae), seven genera (Crematogaster Lund, Pheidole Westwood, Pogonomyrmex Mayr, Camponotus Mayr, Brachymyrmex Mayr, Dorymyrmex Mayr, and Pseudomyrmex Lund) and 13 species (Table 1).

Brachymyrmex musculus was the most abundant species within the disturbed site, whereas Camponotus zonatus and Pseudomyrmex gracilis were the less abundant in that same site. On the other hand, Dorymyrmex pyramicus was the most abundant species, while Pheidole skwarrae and Pheidole tepicana were the less abundant species in the conserved site (Table 1).

Repeated measures ANOVA, showed a significant effect of sampling time on ant abundance $\left(\mathrm{F}_{3,39}=9.52 ; P=0.0473\right)$. However, the Bonferroni test showed that sampling time only affected the abundance of Brachymyrmex musculus (the most abundant species in the disturbed site) and Dorymyrmex pyramicus (the most abundant species in the conserved site). Both species were significantly more abundant in the morning sampling than in the evening one $(P<0.05)$. The ANOVA test also showed a significant effect of disturbance on ant abundance $\left(\mathrm{F}_{12,24}=5.06 ; P=0.0001\right)$. The post-

hoc Bonferroni test showed that Pheidole tepicana, P. skwarrae, Pogonomyrmex barbatus and Dorymyrmex pyramicus were significantly more abundant in the conserved site than in the disturbed one $(P<0.05)$. Contrastingly, Brachymyrmex musculus was significantly more abundant in the disturbed site. 
Table 1. Ant species, feeding guild and number of ants collected on the disturbed (D) and conserved $(C)$ sites within the Zapotitlan Valley, Puebla.

\begin{tabular}{|c|c|c|c|c|c|}
\hline Subfamily & Species & Feeding guild & $\begin{array}{c}\text { Individuals } \\
\text { (D) }\end{array}$ & $\begin{array}{c}\text { Individuals } \\
\text { (C) }\end{array}$ & Total \\
\hline \multirow[t]{5}{*}{ Myrmycinae } & $\begin{array}{l}\text { Crematogaster } \\
\text { torosa } \\
\text { (Mayr 1870) }\end{array}$ & Generalists $^{2}$ & 46 & 282 & 328 \\
\hline & $\begin{array}{l}\text { Crematogaster } \\
\text { distans (Mayr } \\
1870 \text { ) }\end{array}$ & Generalists $^{2,4}$ & 442 & 179 & 621 \\
\hline & $\begin{array}{l}\text { Pheidole } \\
\text { skwarrae } \\
\text { (Wheeler 1934) }\end{array}$ & Granivores $^{1}$ & 0 & 3 & 3 \\
\hline & $\begin{array}{l}\text { Pheidole } \\
\text { tepicana } \\
\text { (Pergande 1986) }\end{array}$ & Granivores $^{1}$ & 0 & 3 & 3 \\
\hline & $\begin{array}{l}\text { Pogonomyrmex } \\
\text { barbatus (Smith } \\
1858)\end{array}$ & Granivores $^{1,5}$ & 63 & 341 & 404 \\
\hline \multirow[t]{5}{*}{ Formicinae } & $\begin{array}{l}\text { Camponotus } \\
\text { planatus } \\
\text { (Roger 1863) } \\
\end{array}$ & Generalists $^{2}$ & 44 & 59 & 103 \\
\hline & $\begin{array}{l}\text { Camponotus } \\
\text { atriceps (Smith } \\
1858 \text { ) }\end{array}$ & Generalists $^{4,5}$ & 25 & 53 & 78 \\
\hline & $\begin{array}{l}\text { Camponotus } \\
\text { lespesii } \\
\text { (Emery 1894) } \\
\end{array}$ & Generalists $^{2}$ & 3 & 25 & 28 \\
\hline & $\begin{array}{l}\text { Camponotus } \\
\text { zonatus } \\
\text { (Emery 1894) }\end{array}$ & Generalists $^{2}$ & 2 & 6 & 8 \\
\hline & $\begin{array}{l}\text { Brachymyrmex } \\
\text { musculus (Forel } \\
\text { 1899) }\end{array}$ & Generalists $^{2,4}$ & 1388 & 697 & 2085 \\
\hline \multirow[t]{2}{*}{ Dolichoderinae } & $\begin{array}{l}\text { Dorymyrmex } \\
\text { bicolor } \\
\text { (Wheeler 1906) }\end{array}$ & Generalists $^{3}$ & 71 & 13 & 84 \\
\hline & \begin{tabular}{|l|} 
Dorymyrmex \\
pyramicus (Roger \\
1863 )
\end{tabular} & Generalists $^{4}$ & 373 & 1130 & 1503 \\
\hline Pseudomyrmecinae & $\begin{array}{l}\text { Pseudomyrmex } \\
\text { gracilis } \\
\text { (Fabricus 1804) }\end{array}$ & Predators $^{2,5}$ & 2 & 4 & 6 \\
\hline
\end{tabular}

${ }^{1}$ Rojas 2001; ${ }^{2}$ Silvestre et al 2003; ${ }^{3}$ Ríos-Casanova et al. 2004; ${ }^{4}$ Fisher y Cover $2007 ;{ }^{5}$ Guzmán-Mendoza et al. 2010 
The highest specific richness was found in the conserved site (13 species). The disturbed site had 11 species of ants. Ant diversity was higher in the conserved site (0.7) than in the disturbed one (0.54).

\section{Effect of disturbance factors on the ant community}

Results of the CCA showed that the " $x$ " and " $y$ " axes explained $52.3 \%$ and $36.2 \%$, respectively, of the total variability of ant species abundances (Fig. 1). Pheidole tepicana and $P$. skwarrae were located on the lowest values for the disturbance factors, suggesting that these species could be highly sensitive to disturbance. On the contrary, Brachymyrmex musculus and Dorymyrmex bicolor are located on the high values of disturbance factors, indicating that these species tolerate disturbed habitats.

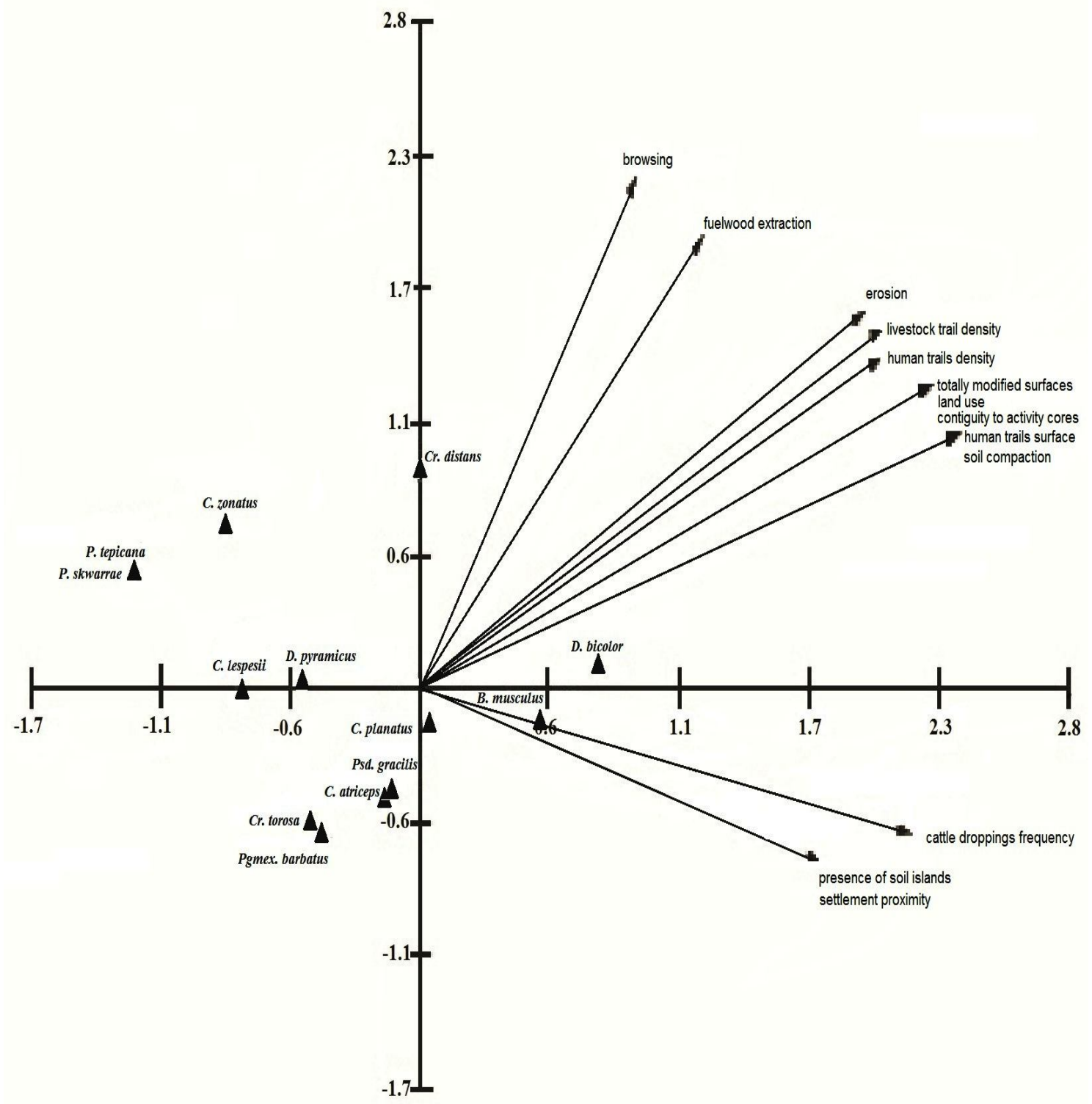

Figure1. Ordination (CCA, box plot) of ant species (triangles) in relation to 15 disturbance factors (arrows) that were combined into a single index such as Martorell and Peters (2005) have suggested. 


\section{Feeding guilds}

From the 13 ant species collected, there were three granivore species (Pheidole skwarrae, P. tepicana and Pogomomyrmex barbatus), one predator (Pseudomyrmex gracilis) and nine generalist foragers (Table 1). The communities of ants from both sites had a functional similarity index of $72 \%$. All the feeding guilds were found in both sites.

\section{Discussion}

\section{Disturbance index}

Soil compaction and cattle paths (the most important disturbance factors within the Zapotitlan Valley) may have a negative effect on the ant community, because soil compaction caused by cattle may prevent ants from building their nests underneath the soil surface and/or may destroy the nests already built by ants (Tizón et al., 2010). Moreover, disturbance factors have an indirect effect on ant behavior. For instance, soil compaction prevents the normal development of plant roots, and favors soil impermeability to water as well as a decrease in gas exchange; thus, preventing the establishment of diverse plant species (Hallmark and Barber, 1981; Davis et al., 1983; Abercombie, 1990; Carrillo, 2003; Philpott et al., 2010). Consequently, there is a decrease in plant coverage together with a change in temperature and humidity. A decrease in vegetation coverage might reduce feeding resources and may expose the chemical signals of ants to rain and wind, so that communication among individuals may be affected negatively (Rojas, 2001). Consequently, ant density may decrease (Bustos et al., 1997) and the ant community may change from being rich in species and feeding habits to a poor community with a few dominant species and generalist feeding habits (Carrol and Risch, 1983; Perfecto and Vandermeer, 1996).

\section{Abundance, species richness and diversity of ants}

A total of 13 ant species were collected in this study. Other studies conducted in the same locality have found a much higher species richness. For instance, Ríos-Casanova et al. (2004) recorded 28 ant species, whereas Guzmán-Mendoza et al. (2010) reported 27 ant species. The differences in species richness found in those studies and ours may be due to the number of traps and time of collection. Ríos-Casanova et al. (2004) and Guzmán-Mendoza et al. (2010) used 400 and 20 traps during three and one years, respectively; whereas we only used 20 traps (each site) on a period of 10 days. Therefore, the species richness obtained in this study is relatively high; moreover, 11 out of the 13 ant species recorded are new records for the Zapotitlan Valley. Among the species recorded in this study, Pogonomyrmex barbatus and Camponotus atriceps are the only two species out of 13 species recorded that have been previously registered in the locality (Ríos-Casanova et al., 2004; Guzmán-Mendoza et al., 2010).

The high number of new ant species recorded in our study may be attributed to a great variability in time and space that may be experiencing the ant community in the Zapotitlan Valley (Rico-Gray et al., 1998; Guzmán-Mendoza et al., 2010). Another possibility is that the number of ant species collected in our study may be associated with the methodology, since half of the pitfall traps were placed on the soil surface and the other half were placed on the surrounding vegetation at $1 \mathrm{~m}$ in height. Contrastingly, 
in other studies, traps have been placed only on the soil surface (Ríos-Casanova et al., 2004; Guzmán-Mendoza et al., 2010).

As for ant activity, it has been recorded that the highest activity of ants occurs early in the morning, when temperature is not that high (Kaspari, 2000). In our study, most ant species had a similar abundance on the morning and the evening hours. However, Brachymyrmex musculus and Dorymyrmex pyramicus were significantly more abundant during the morning. This pattern has been previously recorded for these same ant species in other studies (Tobin, 1994; Andersen, 1997; Davidson, 1997). It has been proposed that the greater abundance of these ant species during the morning is associated with their behavior as submissive opportunists (Andersen, 2010). That is, these ants constitute an unspecialized functional group, often with wide habitat distribution, but they are dominant only when the behavioral dominance of other species is low (Andersen, 2010). In our study, most ant species distribute their activity throughout the day, so that B. musculus and D. pyramicus can be more abundant and competitive during the morning. This may be the reason why $B$. musculus and $D$. pyramicus are more abundant during the morning, which is when they can compensate their submissive behavior (Cerdá and Cros, 1997).

Disturbance had a negative effect on ant diversity, such that there was a lower diversity index in the disturbed site compared with the conserved site. Besides, the ant community was dominated by only three ant species: B. musculus, $C$. distans and $D$. pyramicus (Table 1). These three species are generalists and either can be very successful at competing for resources with other organisms $(C$. distans) or have developed successful strategies of feeding (change their behavioural forager like $B$. musculus and D. pyramicus; Brown, 2000; Rojas, 2001; Ríos-Casanova et al., 2004; Fisher and Cover, 2007; Andersen, 2010). In any case, the behavior of these three species may cause a decrease in the diversity of the community (Rojas et al., 2004).

The conserved site showed a higher diversity of ants than the disturbed one. Moreover, Pheidole skwarrae and P. tepicana were recorded only in the conserved site. The higher diversity of ants in this site may be attributed to the availability of a greater number of microhabitats and resources that can be used by ants (Bustos et al., 1997). For instance, in the conserved site, ants may be able to find decomposing wood, rocks, litterfall and shrubs to build their nests as well as to obtain food (Rojas, 2001; Blüthgen and Feldhaar, 2010). Therefore, the intrinsic characteristics of the conserved site may favor niche partition by different ant species and thus, reducing ant competition and allowing the maintenance of a highly diverse community (Bustos et al., 1997; Cerdá and Cros, 1997).

\section{Disturbance factors and changes in the community of ants}

Results from the CCA showed that the horizontal and vertical axes explained 52.3\% and $36.2 \%$ of the total variability in species abundance. Actually, it has been shown that factors explaining more than $30 \%$ of variability are very important (Ter Braak, 1987). The CCA showed that most ant species were grouped by the lowest values of the disturbance factors (left side in Fig. 1). The ant species Pheidole tepicana and $P$. skwarrae were negatively affected by disturbance, such that they were found only in the conserved site. Therefore, these species seem to be sensitive to environmental changes and thus, may be considered as indicators of disturbance. According to Kremen et al. (1993), an indicator species of disturbance is defined on the basis of its presence/absence in sites with different levels of disturbance and/or on differences in its 
abundance when comparing sites experiencing different levels of disturbance. The ant species Pogonomyrmex barbatus was significantly less abundant in the disturbed site so, we can consider $P$. barbatus as an indicator species. However, the CCA grouped $P$. barbatus with species that were not significantly affected by disturbance. This result suggests that $P$. barbatus is not directly affected by the disturbance factors estimated, but that may be indirectly affected by them through changes in microclimate and availability of resources associated with disturbance. Similar results have been previously recorded for this same ant species, Johnson (2000) found that the pattern of microdistribution of $P$. barbatus may be caused indirectly by soil texture, which has a direct effect on plant species distribution and hence the seeds available to ants. Moreover, Gordon et al. (2005) showed that the requirements imposed by external conditions have a strong influence on the distribution of this ant species and their colonies sequence.

Other ant species with elevated abundance on disturbance site were B. musculus and $D$. bicolor. These species were more abundant in sites with high values of disturbance factors, especially of those related with cattle and land degradation. Because $B$. musculus was significantly more abundant in disturbed sites, it can be considered as an indicator species, tolerant and/or favored by disturbance. MacGown et al. (2007) reported that populations of $B$. musculus grow and spread out explosively in anthropogenically-disturbed habitats.

Although, Dorymyrmex bicolor also showed to be tolerant to disturbance factors; its abundance was not significantly affected by disturbance, which prevents us from considering it as an indicator species.

\section{Feeding guilds}

Six feeding guilds of organisms living in soil and litterfall have been recognized for Mexico (Rojas, 2001; Ríos-Casanova et al., 2004): predators, granivores, omnivores, mycophagous, parasitic and generalists. Most of the ant species collected in our study are generalists (Table 1); except for ants within the Pseudomyrmex, Pheidole and Pogonomyrmex genera, the former being predator and the other two, granivores (RíosCasanova et al., 2004). In our study, Pheidole ants were recorded only in the conserved site and their abundance was not high, therefore, species from this genus seem to be sensitive to disturbance factors (Torres, 1984). In the Zapotitlan Valley, soil compaction and the abundance of cattle paths prevent the establishment of plants from which Pheidole species may feed (Philpott et al., 2010). Besides, those disturbance factors may cause microclimatic changes that affect negatively the distribution of Pheidole ants in the disturbed site. However, in order to determine the microclimatic factors that are affected by disturbance as well as the intensity and directionality of their change, more studies are needed.

The other granivore ant, Pogonomyrmex barbatus, was also sensitive to disturbance factors. Although it was recorded on both sites, its abundance was significantly lower in the disturbed site. This result shows that, like Pheidole species, disturbance has a negative effect on the abundance of $P$. barbatus, probably because in the disturbed site less plants can establish and, therefore, there is a lower availability of seeds. Therefore, is reasonable considering that generalist species use a great variety of resources throughout the year (i.e. insects or parts of them, animal and plant exudates), so that they do not depend upon the seasonal availability of specific resources (Whitford, 
1978). Contrastingly, granivore species depend upon the availability of seeds and fruits, which are more abundant after the rainy season; and the rest of the year these species depend from stored food. Therefore, if there is a lost of vegetal species by disturbance, granivore ants will be seriously affected and it will be hard for them to find food (Brown et al., 1986).

Functional similarity (fs) of the ant community between the disturbed and conserved sites was elevated $(72 \%)$. This suggests that even when the granivore guild was negatively affected by disturbance, the functional structure of both ant communities is maintained. Moreover, our results suggest that ecological equivalents must exist in both sites. Silvestre et al (2003) used the same similarity index to compare ant communities in Brazil. They found that between a conserved and a disturbed site, the species composition was different but ecological equivalents existed on both sites ( $\mathrm{fs}=78.1 \%$ ). Results from Silvestre et al. (2003) showed that the only difference between sites was the number of species of the generalized Camponotini guild. Therefore, they considered the guild as a disturbance indicator. Accordingly, in our study, the granivore guild of ants can be considered an indicator group of soil compaction and cattle paths whthin the Zapotitlan Valley.

Our sampling method was restrictive to a single type of bait and two strata where ants could be found. Therefore, it is possible that not all of the feeding guilds of ants within the community were collected and thus, the similarity between the two ant communities may change if the sampling method is modified and a greater diversity of baits are used, as has been recorded by Bestelmeyer and Ríos-Casanova (2010).

Summarizing, the use of a quantitative method to determine the index of anthropogenic disturbance allows an objective selection of sites with contrasting disturbance. Moreover, this method facilitated the determination of the disturbance factors affecting the ant community. Our results showed that actually soil compaction and cattle paths are affecting the ant community in the Zapotitlan Valley. Differences in the abundance of each ant species between sites and results from the CCA suggest that approximately half of the species are affected by these disturbance factors. This pattern is also shown by the differences found in ant diversity between sites. The CCA and ANOVA analyses showed that Pheidole tepicana, P. skwarrae and P. Barbatus were highly sensitive to disturbance, whereas Brachymyrmex musculus was favored by disturbed habitats; therefore, they can be considered as indicator species. Even when there were not differences in the functional diversity between sites, the granivore species were negatively affected by disturbance, whereas all other species were not affected. Granivore organisms have a strong influence on the structure of the plant community, depending upon the pairwise granivore-plant interactions (Golley and Gentry, 1964; Wight and Nichols, 1966). Therefore, local extinction of granivore species may have an effect on other interactions within the community (i.e. seed dispersal; Rissing, 1986). Moreover, the local loss of an ant species can cause a decrease in species diversity within the community, and thus, a greater sensitivity to environmental changes (Begon et al., 1996). Then, even when our results showed a negative effect of disturbance only in the granivore ant guild, we cannot discard other effects through the trophic web.

The results obtained in this study can be useful for future studies in which disturbance is evaluated. Thus, by identifying the presence/absence of the five indicator species that we recorded, disturbance on a specific site can be evaluated rapidly and inexpensively. 
Acknowledgments. We thank Luis Quiroz Robledo for the identification of ant species, Pedro Guadalupe Miranda for field assistance, and the authorities and people of the Zapotitlan Valley for allowing us to conduct this study. S.P. Rivas-Arancibia was financially supported by PROMEP (BUAP-PTC-245, PROMEP/103.5/10/7296) to conduct this study.

\section{REFERENCES}

[1] Abercombie, R.A. (1990): Root distribution of avocado trees on a sandy loam soil as affected by soil compaction. - Acta Horticulturae 275: 505-512.

[2] Andersen, A.N. (1991): Sampling communities of ground-foraging ants: Pitfall catches compared with quadrant counts in an Australian tropical savanna. - Austral Ecology 16(3): 273-279.

[3] Andersen, A.N. (1995): A classification of Australian ant communities, based on functional groups which parallel plantlife-forms in relation to stress and disturbance. - Journal of Biogeography 22: 15-29.

[4] Andersen, A.N. (1997): Using Ants as bioindicators: Multiscale Issues in Ant Community Ecology. - Conservation Ecology 1(1): 8.

[5] Andersen, A.N. (2010): Using ants as indicators of ecosystem change. - In: Lach, L. Parr, C.L. Abbott, K.L. (eds.) Ant Ecology. Oxford University Press, United States.

[6] Bestelmeyer, B. and Ríos-Casanova, L. (2010): Field techniques for sampling ants. In: Lach, L. Parr, C.L. Abbott, K.L. (eds.) Ant Ecology. Oxford University Press, United States.

[7] Begon, M.C., Harper, R. and Townsend, C.R. (1996): Ecology, individuals, populations and communities. - Cambridge, M.A, Blackwell Science Ltd.

[8] Blüthgen, N. and Feldhaar, H. (2010: Food and shelter: how resources influence ant ecology. - In: Lach, L. Parr, C.L. Abbott, K.L. (eds) Ant Ecology. Oxford University Press, United States.

[9] Bolton, B., Alpert, G., Ward, P.S. and Naskrecki, P. (2006): Bolton's catalogue of ants of the World. - Harvard University Press, Cambridge Mass.

[10] Brito, M.Y., Simonetti, J.A. and Vázquez, M.L. (2010): Caracterización de la mirmecofauna y su relación con las practicas adoptadas en un sistema de producción agrícola urbano. - Fitosanidad 4 (14): 219-227.

[11] Brown, J.H., Davidson, D.W., Munger, J.C. and Inouye, R.S. (1986): Community Ecology: The desert granivore system. - In: Diamond, J. and Case, T.J. (eds.) Community Ecology. Harper \& Row, Publisher, New York.

[12] Brown, W.L. Jr. (2000): Diversity of ants. - In: Agosti, D. Agosti, J.D. Majer, L. E. Alonso and Gschultz, T.S. (eds.) Ants: Standard Methods for Measuring and Monitoring Biodiversity. Smithsonian Institution Press, London.

[13] Bustos, H.J. and Ulloa-Chacón, P. (1997): Mirmecofauna y perturbación en un bosque de niebla neotropical (Reserva Natural Hato Viejo, Valle del Cauca, Colombia).

Revista de Biología Tropical 44(3): 259-266.

[14] Carrillo, J. 2003. Manejo de Pasturas. - EEA INTA Balcarce. Ed. INTA Balcarce.

[15] Carroll, C.R. and Risch, S.J. (1983): Tropical annual cropping systems: ant ecology. - Environmental Management 7: 51-57.

[16] Castro, D.S., Vergara, C.C. and Arellano, U.C. (2008): Distribucion de la riqueza y composición de hormigas del suelo a lo largo de un gradiente altitudinal en el refugio de la vida silvestre Laquipampa, Lambayeque-PERU. - Ecología aplicada 7 (1 y 2): 89103.

[17] Cerdá, X. and Cros, S. (1997): Thermal disruption of transitive hierarchies in Mediterranean ant communities. - Journal of Animal Ecology 66: 363-374. 
[18] Davidson, D.W. (1997): The role of resource imbalances in the evolutionary ecology of tropical arboreal ants. - Biological Journal of the Linnaean Society London 61: 153-181.

[19] Davidson, D.W., Cook, S.C., Snelling, R.R. and Chua, T.H. (2003): Explaining the abundance of ants in lowland tropical rainforest canopies. - Science 300: 969-972.

[20] Davis, G.R., Nielsen, W.A. and Mac Davitt, J.G. (1983): Root distribution of Pinus radiata related to soil characteristics in five Tasmanian soils. - Australian Journal Soil Research 21: 165-171.

[21] Delfino, M.A. and Buffa, L.M. (2000): Algunas interacciones plantas-áfidoshormiga en Córdoba (Argentina). - Zoologica Baetica 11: 3-15.

[22] Del Toro, V.M., Mackay, W.P., Rojas, P. and Zapata, M. (2009): Hormigas (Himenóptera: Formicidae) de Tabasco: explorando la diversidad de la mirmecofauna en las selvas tropicales de baja altitud. - Dugesiana 16(1): 1-14.

[23] Fisher, B.L. and Cover, S.P. (2007): Ants of North America: A guide to the genera. - Berkeley \& Los Angeles, California.

[24] Golley, F.B. and Gentry, J.B. (1964): Bioenergetics of the Southern harvester ant Pogonomyrmex badium. - Ecology 45: 217-225.

[25] Gordon, M.D., Chu, J., Lillie, A., Tissot, M. and Pinter, N. (2005): Variation in the transition from inside to outside work in the red harvester ant Pogonomyrmex barbatus. - Insectes Sociaux 52: 212-217.

[26] Grytnes, J.A. and McCain, C.M. (2007): Elevational Trends in Biodiversity. Encyclopedia of Biodiversity 2:1-8.

[27] Gurevitch, J. and Chester, S.T. Jr. (1986): Analysis of Repeated Measures Experiments. - Ecology 67(1): 251-255.

[28] Guzmán-Mendoza, R., Castaño-Meneses, G. and Herrera-Fuentes. M.C. (2010): variación especial y temporal de la diversidad de hormigas en el jardín botánico del valle de Zapotitlán de las Salinas, Puebla.- Revista Mexicana de Biodiversidad 81: 427- 435.

[29] Hallmark, W.B. and Barber, S.A. (1981): Root growth and morphology, nutrient uptake, and nutrient status of soybeans as affected by soil K and bulk density. Agronomy Journal 73: 779-782.

[30] Hernández, C.O. (2005): Polinización y Hormigas. - Cambridge University Press.

[31] Hintze, J. (2006): NCSS, PASS ans GESS. - NCSS. Kaisville, Utah.

[32] Hoffmann, B.D. and Andersen, A.N. (2003): Responses of ants to disturbance in Australia, with particular reference to functional groups. - Austral Ecology 28: 444-464.

[33] Johnson, D.E. (1998): Métodos multivariados aplicados al análisis de datos. International Thomson, México.

[34] Johnson, R.A. (2000): Habitat segregation based on soil texture and body size in the seed-harvester ants Pogonomyrmex rugosus and P. Barbatus. - Ecological Entomology 25: 403-412.

[35] Kaspari, M. and Majer, J. (2000): Using ants to monitor environmental change. - In D. Agosti, J. Mayer, L. Alonso and T. Schultz (eds.) Ants, Standard methods for measuring and monitoring biodiversity. Smithsonian Institution Press, London.

[36] Kovach, W.L. (2004): MVSP-A MultiVariate Statistical Package for Windows. Ver. 3.13. - Kovach Computing Services. Pentraeth, Wales, UK.

[37] Kremen, C., Colwell, R.K., Erwin, T.L., Murphy, D.D., Noss, R.F. and Sanjayan, M.A. (1993): Terrestrial artgropodo assemblaje: Their use in conservation planning. Conservation Biology 7: 796-808.

[38] Lobry DeBruyn, L.A. (1999): Ants as bioindicators of soil function in rural environments. - Agriculture. Ecosystems and Environment 74: 425-441. 
[39] Luque, G.G., Reyes-López, J.L. and Fernández, H.J. (2002): Estudio Faunístico de las Hormigas (Himenóptera: Formicidae) de la cuenca del Río Guadiamar: Primeras aportaciones. - Boletin de la Sociedad Entomológica Aragonesa 30:153-159.

[40] Majer, J.D. (1983): Ants: bioindicators of mine site rehabilitation, land use and land conservation. -Environmental Management 7: 375-383.

[41] MacKay, P.W. and MacKay, E. (1989): Clave de los géneros de Hormigas en México (Hymenóptera: Formicidae). - Memorias del II Simposio Nacional de Insectos Sociales, Morelos. 1-82.

[42] MacGown, J.A., Brown, R.L., Hill, J.G. and Layton, B. (2007): Carpenter ants (Hymenoptera: Formicidae: Camponotus) of Mississippi. - Mississippi Agricultural and Forestry Experiment Station Technical Bulletin 1158, 28.

[43] Magurran, A.E. (1988): Ecological diversity and its measurement. - Princeton University Press, New Jersey.

[44] Martínez, N.D. (1996): Defining and measuring functional aspects of biodiversity. In: Gaston, K.J. (ed.) Biodiversity: a biology of numbers and difference. London, Blackwell Science Ltd.

[45] Martorell, C. and Peters, E.M. (2005): The measurement of chronic disturbance and its effects on the threatened cactus Mammillaria pectinifera. - Biological Conservation 124: 199-207.

[46] Montaña, C. and Valiente-Banuet, A. (1998): Floristic and life-form diversity along an actitudinal gradient in an intertropical semiarid mexican region. - The Southwestern Naturalist 43: 25-39.

[47] Perfecto, I. and Vandermeer, J. (1996): Microclimatic changes and the indirect loss of ant diversity in a tropical agroecosystem. - Oecologia 108: 577-582.

[48] Philpott, S.M., Perfecto, I., Armbrechcht, I. and Parr, C.L. (2010): Ant diversity and function in disturbed and changing habitats. - In: Lach, L. Parr, C.L. Abbott, K.L. (eds.) Ant Ecology. Oxford University Press, United States.

[49] Redolfi, A., Tinaut, A., Pascual, F. and Campos, M. (2003): Activity pattern of Tapinoma nigerrima (Nylander) and Crematogaster scutellaris (Olivier) (Hymenopterae, Formicidae) in an olive grove and the laboratory. - Zoologica Baetica 13: 37-55.

[50] Rice, W.R. (1989): Analyzing Tables of Statistical Test. -Evolution 43(1): 223- 225.

[51] Rico-Gray, V., Palacios-Ríos, M., García-Franco, J.G. and Mackay, W.P. (1998): Richness and seasonal variation of ant-plant associations mediated by plant-derived food resources in the semiarid Zapotitlan Valley, México. - American Midland Naturalist 140: 21-26.

[52] Ríos-Casanova, L., Valiente, B.A. and Rico-Gray, V. (2004): Las Hormigas del Valle de Tehuacán (Himenóptera: Formicidae): una comparación con otras zonas áridas de México. - Acta Zoológica Mexicana 20(1): 37-54.

[53] Rissing, S.W. (1986): Indirect effects of granivory by harvester ants: plant species composition and reproductive increase near ant nests. - Oecologia 68: 231-234.

[54] Rojas, F.P. (2001): Las hormigas del suelo en México: Diversidad, Distribución e Importancia (Hymenoptera: Formicidae). - Acta Zoológica Mexicana 1: 189- 238.

[55] Rzedowski, J. (1978): Vegetación de México. - Limusa, México.

[56] Silvestre, R. (2000): Estrutura de comunidades de hormigas do Cerrado. Ribeirão Preto, SP, FFCL-USP. -Tesis de Doctorado.

[57] Silvestre, R., Brandão, C.R.F. and Da Silva, R.R. (2003): Grupos funcionales de hormigas: el caso de los gremios del Cerrado. - In: Fernández, F. (ed.) Introducción a las hormigas de la región Neotropical, Bogotá Colombia. Insituto de Investigaión de Recursos Biológicos Alexander Von Humboldt, Colombia.

[58] Ter Braak, C.J. (1987): The analysis of vegetation-environment relationships by canonical correspondence analysis. - Vegetation 69: 69-77. 
[59] Tizón, F.R., Peláez, D.V. and Elía, O.R. (2010): Efecto de los cortafuegos sobre el ensamble de hormigas (Hymenoptera, Formicidae) en una región semiárida, Argentina. - Iheringia, Sér. Zool. Porto Alegre 100(3): 216-221.

[60] Tobin, J.E. (1994): Ants as primary consumers: diet and abundance in the Formicidae. - In: Hunt, J.H. and Nalepa, C.A. (eds.) Nourishment \& Evolution in Insects Societies. Westwiew Press/ Oxford \& IBH Publ. Co.

[61] Torres, J.A. (1984): Diversity and distribution of ant communities in Puerto Rico. Biotropical 16:296-303.

[62] Valiente-Banuet, A., Rojas-Martínez, A., Arizmendi, M.C. and Dávila, P. Pollination biology of two columnar cacti (Neobuxbaumia mezcalaensis and Neobuxbaumia macrocephala) in the Tehuacan Valley, central México. - American Journal of Botany 84: 452-455.

[63] Vázquez, B.M. (1998): Hormigas (Hymenoptera:Formicidae) colectadas en necrotrampas, en tres localidades de Jalisco, México. - Tesis de Licenciatura, centro universitario de Ciencias Biológicas y Agropecuarias, Universidad de Guadalajara. Zapopan, Jalisco.

[64] Vázquez-Bolaños, M. and Mackay, W.P. (2004): Una especie nueva de la hormiga cosechadora del género Pogonomyrmex (Hymenoptera: Formicidae) de México. - Sociobiology 44 (2): 283-287.

[65] Vázquez-Bolaños, M. (2007): Una especie nueva del género Tetramorium Mayr (Hymenoptera: Formicidae) de Mascota, Jalisco, México. - Dugesiana 14(2): 9397.

[66] Vittar, F. (2008): Hormigas (Hymenoptera: Formicidae) de la Mesopotamia Argentina. - INSUGEO, Miscelánea 17(2): 447-466.

[67] Whitford, W.G. (1978): Structure and seasonal activity of Chihuahuan desert ants communities. - Insectes Sociaux 25: 79-88.

[68] Wight, J.R. and Nichols, J.T. (1966): Effects of harvest ants on production of saltbush community. - Journal of Range Management 19: 68-71.

[69] Zar, J.H. (1999): Biostatistical Analiysis. - Editorial Interactive Composition Corporation, United Stated.

[70] Zavala-Hurtado, J.A. (1982) Estudios ecológicos en el valle semiárido de Zapotitlán.

Puebla. I. Clasificación numérica de la vegetación basada en atributos binarios de presencia o ausencia de las especies. - Biotica 1(7): 99-120. 